\title{
The complexity, function, and applications of RNA in circulation
}

\author{
Alton Etheridge ${ }^{1}$, Clarissa P. C. Gomes ${ }^{2,3}$, Rinaldo W. Pereira ${ }^{3}$, David Galas ${ }^{1,4}{ }^{*}$ and Kai Wang ${ }^{2}$ * \\ 1 Pacific Northwest Diabetes Research Institute, Seattle, WA, USA \\ 2 Institute for Systems Biology, Seattle, WA, USA \\ ${ }^{3}$ Graduation on Genomic Sciences and Biotechnology, Catholic University of Brasilia, Brasília, Brazil \\ ${ }^{4}$ Luxembourg Centre for Systems Biomedicine, University of Luxembourg, Luxembourg, Luxembourg
}

\section{Edited by:}

Andrey Turchinovich, German Cancer Research Center, Germany

\section{Reviewed by:}

Andrey Turchinovich, German Cancer Research Center, Germany Natalia Elfimova, University Hospital of Cologne, Germany

Melissa Piper, The Ohio State

University, USA

\section{${ }^{*}$ Correspondence:}

Kai Wang, Institute for Systems Biology, 401 Terry Avenue North, Seattle, WA 98109, USA e-mail: kwang@systemsbiology.org; David Galas, Pacific Northwest Diabetes Research Institute, 720 Broadway, Seattle, WA 98122, USA e-mail:dgalas@pnri.org
Blood carries a wide array of biomolecules, including nutrients, hormones, and molecules that are secreted by cells for specific biological functions. The recent finding of stable RNA of both endogenous and exogenous origin in circulation raises a number of questions and opens a broad, new field: exploring the origins, functions, and applications of these extracellular RNA molecules. These findings raise many important questions, including: what are the mechanisms of export and cellular uptake, what is the nature and source of their stability, what molecules do they interact with in the blood, and what are the possible biological functions of the circulating RNA? This review summarizes some key recent developments in circulating RNA research and discusses some of the open questions in the field.

Keywords: microRNA, exosomes, microvesicles, cell-cell communication, exogenous RNA
Coordination of the activities of different cells in the body is vital for multi-cellular organisms. For this purpose, at least three different types of intercellular communication systems have evolved. Physical interactions between cells through cell surface protein engagement like that between receptors and ligands are used to transmit signals between close, contacting cells (Schonbeck and Libby, 2001; Chillakuri et al., 2012). Gap junctions can also facilitate the transmission of molecular signals between cells (Valiunas et al., 2005; Wolvetang et al., 2007; Lim et al., 2011). Membrane nanotubes or cytonemes that extend up to $100 \mu \mathrm{m}$ in length are physical connections that also allow communication between cells that are not immediately adjacent to each other (Gerdes and Carvalho, 2008). Multi-cellular organisms have also developed a network of circulating body fluids to deliver nutrients to cells, remove waste molecules, and transmit signals for "long-distance" cell-cell and organ-organ communication. The combination of the circulation system with central and peripheral neural networks, and other short and medium range communication processes, allows cells and organs in an organism to operate in close concert. Some circulating proteins or peptides are well-known for their roles as signaling molecules. These include hormones such as insulin, growth hormone, prolactin, and many other secreted proteins/peptides. In addition to these well-known examples, other biomolecules such as nucleic acids are also exported from cells and are present in various body fluids (Valadi et al., 2007; Weber et al., 2010), although their potential roles in intercellular signaling have not been confirmed. While the discovery of circulating extracellular nucleic acid is not new, having been described as early as 1948 (Mandel and Métais, 1948), there has been a renewed interest in the function and application of circulating nucleic acids due to several, diverse recent findings. These include the discoveries of fetal DNA in maternal blood (Lo and Chiu, 2012), tumor-derived DNA in circulation (Kohler et al., 2011) and stable regulatory non-coding RNA (ncRNA) in body fluids (Cortez et al., 2011).

RNA is generally considered to be an unstable molecule that is subject to degradation and turnover by ubiquitous RNase activity. However, intact RNAs of different types, including both proteincoding RNA (mRNA) and non-coding RNA (ncRNA) have been detected in circulation (Valadi et al., 2007). Some of these RNAs are likely the result of cell lysis through normal cell turnover and are in the process of degradation, reabsorption, or excretion (Turchinovich et al., 2011). However, the abundance and high stability of some of these RNA molecules, especially the short regulatory RNA, microRNA (miRNA), suggests a different scenario: the possibility of a cell-cell communication system through RNA-mediated signals (Lotvall and Valadi, 2007; Turchinovich et al., 2011; Montecalvo et al., 2012). Furthermore, recent studies have shown that exogenous RNA molecules can enter into circulation through the diet or other means, and can potentially be taken up by cells and thereby alter the cellular transcriptome (Semenov et al., 2012; Wang et al., 2012; Zhang et al., 2012a). Many questions remain unanswered, however, including: what are the sources of endogenous and exogenous RNA molecules in circulation, what is (are) the mechanism(s) by which these RNAs enter into circulation, how are they stabilized there, are they taken up by cells, and how are 
they recognized for uptake by cells? Here we review several recent developments in the study of circulating RNAs and their potential functions and possible applications.

\section{EXTRACELLULAR RNA IN BODY FLUIDS}

Among all the circulating nucleic acids, miRNAs are probably the most extensively studied. These small molecules are short, ncRNAs involved in regulating the cellular transcriptome and proteome by destabilizing mRNA and/or attenuating protein translation (Filipowicz et al., 2008; Fabian et al., 2010). The interaction between miRNAs and their cognate mRNA targets is mediated by partial sequence complementarity between the two (Fabian et al., 2010). The RNA-induced silencing complex (RISC), which contains a number of proteins including members of the Argonaute family, the RNA recognition motif containing protein TNRC6B, putative DNA helicase MOV10, among others, is involved in the miRNA-mRNA interaction (Chendrimada et al., 2007).

MicroRNAs were first detected in the blood plasma and serum in 2008 (Chen et al., 2008; Chim et al., 2008; Hunter et al., 2008; Lawrie et al., 2008; Mitchell et al., 2008; Skog et al., 2008) and have subsequently been detected in many other different body fluids including urine, saliva, tears, and breast milk (Park et al., 2009; Hanke et al., 2010; Weber et al., 2010). The total amount and the concentration of individual miRNAs vary widely among the different fluid types (Weber et al., 2010). The potential of circulating miRNAs as biomarkers has been extensively investigated in recent years. miRNAs make good biomarker candidates for several reasons. They are stable in body fluids, which are easy to obtain from patients, they can be easily measured with high sensitivity because they are amplifiable, and some markers and sets of markers have shown profiles associated with specific pathologies. The changes in miRNA levels may be used as a diagnostic tool for several types of cancer (Mitchell et al., 2008; Taylor and GercelTaylor, 2008; Park et al., 2009; Hanke et al., 2010; Huang et al., 2010; Zhao et al., 2010; Moussay et al., 2011; Roth et al., 2011), cardiac damage (Ai et al., 2010; Corsten et al., 2010; Tijsen et al., 2010; Wang et al., 2010a), muscular injury and pathologies (Laterza et al., 2009; Mizuno et al., 2011; Vignier et al., 2013), diabetes (Chen et al., 2008; Erener et al., 2013), liver injury (Laterza et al., 2009; Wang et al., 2009, 2013; Starkey Lewis et al., 2011), among others.

The literature reporting correlations with human disease and pathologies has grown rapidly in the past few years. The number of papers, for example, on changes in circulating miRNAs in cases of myocardial infarction (MI) and cardiac diseases alone has recently exploded. We estimate that more than 30 reports on this specific topic alone have been published since 2009. Some of the circulating miRNAs identified in MI and cardiac diseases have been summarized in Table $\mathbf{1}$.

Efforts have also been made to use circulating miRNAs as a prognostic tool in response to therapeutic treatments (Ma et al., 2012). Furthermore, the possibility of using miRNAs as therapeutics themselves has been considered. It is a very exciting prospect if these molecules can be packaged and released into circulation as stable and perhaps even targeted packages. Applications in this area have taken different approaches. For example, creating synthetic miRNAs designed to target specific disease-associated genes, as used by Suckau et al. (2009) to treat heart failure. In this case, viral vectors containing short hairpin RNAs were administered intravenously in rats to reduce the level of a key regulator of cardiac calcium homeostasis, phospholamban (Suckau et al., 2009). The use of antagomirs to target miRNAs that are upregulated in pathological states has also been demonstrated. For example, an antagomir of miR-133 caused sustained cardiac hypertrophy in mice (Care et al., 2007); antagomirs targeting miR-1 and let$7 \mathrm{f}$ were successfully used in rats to extend neuroprotection after ischemic stroke (Selvamani et al., 2012); mice treated with high doses of an antagomir for miR-126 showed reduced ischemiainduced angiogenesis (van Solingen et al., 2009); and a miR-206 antagomir increased brain-derived neurotrophic factor levels and improved memory function in rats with Alzheimer's disease (Lee et al., 2012). Furthermore, a treatment for hepatitis C virus (HCV) chronic infection using an antagomir for the liver-specific miR-122 is currently in clinical trial (Janssen et al., 2013).

\section{RNA EXPORT, PACKAGING, AND UPTAKE}

While extracellular RNAs were first thought to be molecular debris released by cell lysis (Turchinovich et al., 2011), the difference in the spectrum of RNA within cultured cells and the external medium argues strongly for selective export of some fraction of the circulating RNAs (Wang et al., 2010b). It remains unclear how specific RNAs are targeted for export, and if some are simply released with the cytosol through bulk exocytosis. As free RNA molecules are very likely to be degraded outside the cell, it is generally assumed that circulating RNAs are packaged in some form to avoid RNase degradation. Lipid vesicles, such as exosomes or microvesicles are one type of packaging system used by secreted RNAs (Valadi et al., 2007; Camussi et al., 2011). Exosomes, which are approximately $30-100 \mathrm{~nm}$ in diameter, are formed by fusion of multivesicular bodies with the plasma membrane. Microvesicles are larger $(100 \mathrm{~nm}-1 \mu \mathrm{m})$ and formed by blebbing of the plasma membrane. Both types of vesicles can contain a number of protein and RNA molecules, although the composition varies widely with the origin of the vesicle (Muller, 2012; Huang et al., 2013).

In addition to lipid vesicles, it has been demonstrated that miRNA in the extracellular environment can complex with highdensity lipoproteins (HDL) and at least two RNA-binding proteins in vivo, Argonaute 1 (AGO1) and Argonaute 2 (AGO2), and with nucleophosmin 1 (NPM1) in vitro (Wang et al., 2010b; Arroyo et al., 2011; Turchinovich et al., 2011; Vickers et al., 2011; Turchinovich and Burwinkel, 2012; Wagner et al., 2013). Furthermore, the spectrum of miRNA associated with HDL depends on the health status of an individual (Vickers et al., 2011). However, it is not known if there are other RNA-binding proteins that form similar complexes to protect miRNAs or other types of RNA in circulation.

Besides miRNAs, lipid vesicles also contain a large number of protein-coding RNAs. Roughly 1300 different mRNA transcripts have been identified in lipid vesicles derived from human or mouse cell lines (Valadi et al., 2007). Interestingly, the mRNA composition and abundance in the exosomes differ from that of the original cell, which suggests the contents in the lipid vesicles are selectively packaged rather than included indiscriminately. The levels 


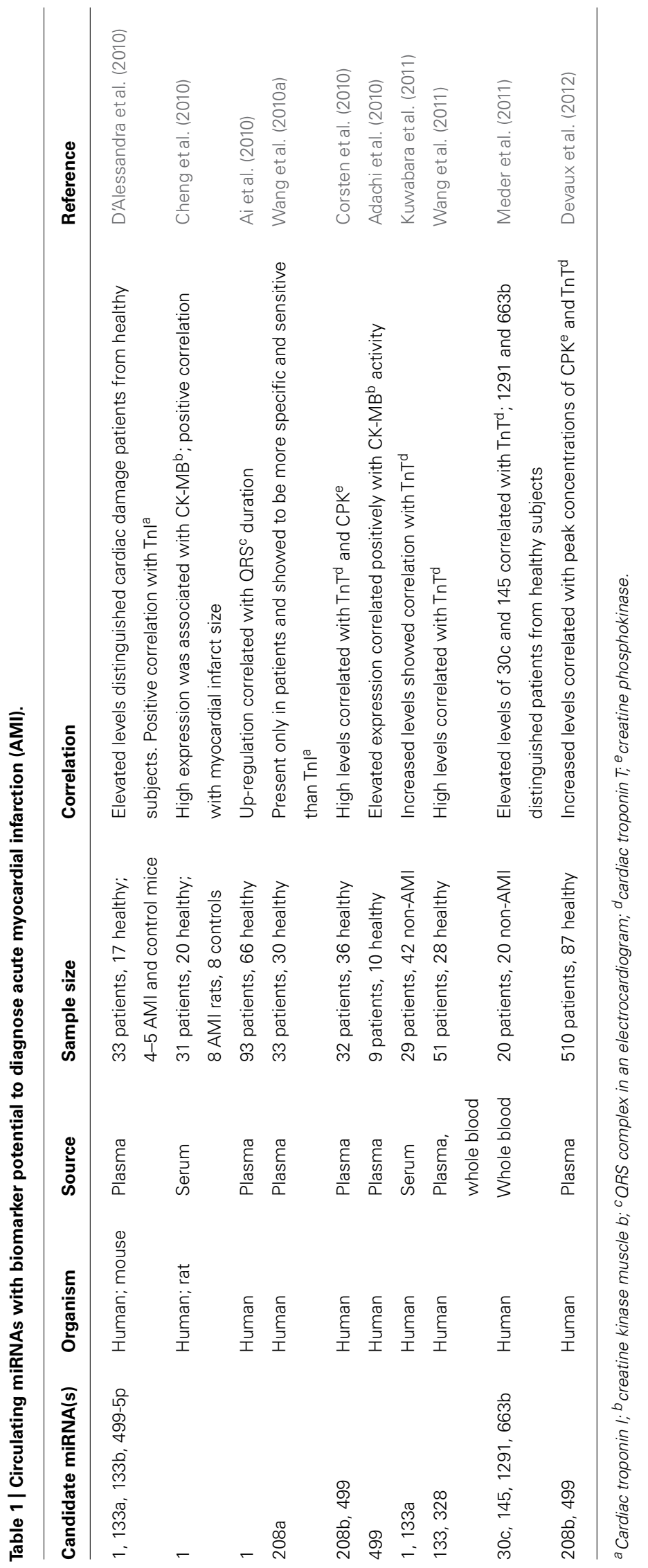


of circulating miRNAs as well as several mRNAs in circulation have been shown to be associated with stages and types of cancers (Sueoka etal., 2005; Mitchell etal., 2008; Taylor and GercelTaylor, 2008; Ohshima et al., 2010; Zhao et al., 2010; Zhang et al., 2012b), pregnancy (Zhong etal., 2008; Rajakumar et al., 2012; Wu et al., 2012; Zhao et al., 2012; Higashijima et al., 2013), and drug-induced liver injury (Miyamoto et al., 2008; Laterza et al., 2009; Wang etal., 2009, 2013; Bala et al., 2012; Su et al., 2012; Okubo et al., 2013).

The idea of using RNA as a mode of intercellular communication is particularly interesting for several reasons. First, RNA can carry information in a simple and efficient way (such as coding for proteins in mRNA), and, second, it can coordinate cellular activity in a fundamental and essential manner (such as microRNA-mediated transcriptome and proteome regulation). It has been demonstrated that cells can export miRNAs, which can be transferred to and are functional in recipient cells (Kosaka et al., 2010; Zhang et al., 2010; Hergenreider et al., 2012). However, it is inherently difficult to test definitively the functioning of an RNA-based communication system in vivo. Conditioned media exchange and co-culture experiments have been used to investigate cell-cell communications, and these methods have been adapted to investigate the possibility of RNA uptake by cells (Liu et al., 2010; Vencio et al., 2011; Yang et al., 2011). Some exosome-derived mRNAs have been shown to be functional in recipient cells (Valadi et al., 2007; Ismail et al., 2013). Furthermore, Ratajczak et al. (2006) showed that microvesicles derived from embryonic stem cells can enhance the survival and expansion of mouse hematopoietic progenitor cells, and are enriched in stem cell related transcripts including Oct-4, Rex-1, Nanog, SCL, and GATA-2. Reporter assays have shown that exosome-derived miRNAs can silence transcripts in recipient cells (Lotvall and Valadi, 2007; Valadi et al., 2007; Camussi et al., 2011; Kogure et al., 2011; Mittelbrunn et al., 2011). While evidence suggests that cultured cells can transfer packaged RNA molecules, it is difficult to demonstrate this as a general mechanism in vivo. One of the most important remaining biochemical questions is how the RNA in circulation is protected, packaged, and delivered to and recognized by their targets. The current lack of knowledge about these questions makes the study of the biological functions of circulating RNA both important and difficult.

Besides protein-coding RNAs and miRNAs, there are other more abundant types of regulatory RNA molecules, such as large intergenic ncRNAs (lincRNAs) and small nucleolar RNAs (snoRNAs) in extracellular vesicles (Huang et al., 2013). A recent characterization of neuronal exosomes found RNAs derived from repeat sequences, as well as mRNA and several types of small RNAs. While a majority of small RNA was tRNA (90\%), other types of small RNAs including miRNA, snoRNA, and small cytoplasmic RNA (scRNA) were also detected (Bellingham et al., 2012). Since both mRNA and miRNA can be taken up and utilized by cells (see earlier paragraph), there is no reason to think that other types of RNA in circulation do not also have functional implications when they are taken up by cells. However, there is currently no direct experimental evidence to support this functional possibility for other types of RNA in circulation.

\section{METHODS USED IN STUDYING RNA IN CIRCULATION}

Microarray, qPCR (quantitative polymerase chain reaction), and sequencing-based approaches are the three major platforms that have been used for miRNA and mRNA profiling. All of these have been widely and successfully applied in assessing the spectra of mRNA and miRNA in cells and tissues. However, due to the relatively low concentration of RNA present in circulation, comprehensive measurement of any circulating RNA is difficult to do accurately and consistently. For miRNAs, the difficulties are compounded by the short lengths of the RNA molecules and the consequent sequence specificity of hybridization free energies. At the moment, the most commonly used method for miRNA profiles is qPCR because of its sensitivity and the limited number of known miRNAs (on the order of 1000 sequences). This method has significant drawbacks as well because of the specificity and differential amplification efficiency of the designed primers. This technique has also been applied to measure the level of specific mRNA sequences in circulation (Wang et al., 2013). Although microarrays have been the gold standard for transcriptome analysis in cells and tissues, the low concentration of RNA in circulation, and the sequence similarity of these short nucleic acid molecules make microarray analysis unsuitable in most cases. The development of next generation sequencing (NGS) has shown promise in measuring circulating RNAs. This platform not only solves some of the miRNA measurement problems related to short and highly similar sequences of miRNAs, but it can provide measurements on a broad spectrum of RNA in a single experiment. Because it does not rely on pre-designed probes or primers, NGS also allows the identification of novel RNA sequences, such as isomirs and exogenous RNAs in circulation (Lee et al., 2010; Wang et al., 2010a, 2012; Semenov et al., 2012). One difficulty with this method is the inherent bias in the preparation of the sequencing libraries. For this reason, absolute measurements of circulating RNA are very difficult, but when carefully done, comparative measurements can be reliable.

\section{EXOGENOUS RNA IN CIRCULATION}

Recent evidence, which we discuss below, suggests that RNAs in circulation are derived not only from cells within the human body, but also from foreign organisms and viruses (Meckes et al., 2010; Pegtel et al., 2010). It has been shown that exogenous RNAs find their way from the outside environment, through diet or from the complex human microbiome (Zhang et al., 2012a). Little is known about how exogenous RNAs are taken up by the gut epithelium from the environment, and there is only very limited and circumstantial evidence so far that these RNAs are functional in the body. However, in keeping with the substantial and growing body of evidence that some human circulating RNA are functional, the possibility that exogenous RNAs, found in the circulation can be taken up and exert specific functions in recipient cells, raises several interesting issues.

A recent report by Zhang et al. (2012a) indicated that exogenous miRNAs ingested from food (rice in this case) could enter into the human circulation and be taken up by and actually function in cells. They found that certain plant miRNAs, including miR-168a, an abundant miRNA in rice, is detectable in human plasma, as well as in plasma from other animals eating a diet containing plant 
material. However, many questions such as how the RNA survives the cooking process and the harsh environment of the digestive tract, as well as how these biomolecules can pass through the gut epithelium, remain largely unanswered. Using Caco-2 cells transfected with synthetic rice miR-168a, Zhang et al. (2012a) found that transfected miR-168a can be packaged by cells into microvesicles and released into culture medium. Furthermore, their work suggests that the microvesicles containing exogenous miRNA can be taken up by cells and interact with endogenous transcripts both in vitro and in vivo. Mature miR-168a sequence has significant sequence homology with a liver-expressed transcript, low-density lipoprotein receptor adaptor protein 1 (LDLRAP1) transcript, raising the possibility that it can suppress the expression of LDLRAP1 through the action of the RISC complex. Indeed, mice fed a rice-containing diet have lower level of LDLRAP1 gene expression than mice fed a normal chow diet, suggesting that miR-168a derived from the rice can affect the level of an endogenous mouse transcript (Zhang et al., 2012a).

Recent work by our lab and others have systematically characterized the composition of RNAs in circulation and revealed that some of the circulating RNAs are derived from a variety of exogenous organisms, including the microbiome (Semenov et al., 2012; Wang et al., 2012, 2013). Using a map-and-remove strategy to analyze small RNA-seq data (after removing sequences mapped to human miRNAs, transcripts, and genomic sequences first), reveals that a significant portion of the total reads are of non-human origin. While some of these exogenous RNAs are derived from the diet, the majority of them are of either fungal or bacterial origins (Wang et al., 2012). The sequences detected implicate a wide range of bacterial phyla, including many already known to reside in the gut microbiome. Although there were not significant differences in the plasma RNA spectra between healthy individuals and those with colorectal cancer or ulcerative colitis, differences can be detected in the plasma of people eating different diets, such as a corn-based diet versus a rice-based diet (Wang et al., 2012).

While these results raise the interesting possibility that exogenous RNAs taken up from the environment can alter gene

\section{REFERENCES}

Adachi, T., Nakanishi, M., Otsuka, Y., Nishimura, K., Hirokawa, G., Goto, Y., et al. (2010). Plasma microRNA 499 as a biomarker of acute myocardial infarction. Clin. Chem. 56, $1183-$ 1185. doi: 10.1373/clinchem.2010. 144121

Ai, J., Zhang, R., Li, Y., Pu, J., Lu, Y., Jiao, J., et al. (2010). Circulating microRNA-1 as a potential novel biomarker for acute myocardial infarction. Biochem. Biophys. Res. Commun. 391, 73-77. doi: 10.1016/j.bbrc.2009.11.005

Arroyo, J. D., Chevillet, J. R., Kroh, E. M., Ruf, I. K., Pritchard, C. C., Gibson, D. F., et al. (2011). Argonaute2 complexes carry a population of circulating microRNAs independent of vesicles in human plasma. Proc. Natl. Acad. Sci. U.S.A. 108, 5003-5008. doi: 10.1073/pnas. 1019055108
Bala, S., Petrasek, J., Mundkur, S., Catalano, D., Levin, I., Ward, J., et al. (2012). Circulating microRNAs in exosomes indicate hepatocyte injury and inflammation in alcoholic, druginduced, and inflammatory liver diseases. Hepatology 56, 1946-57. doi: 10.1002/hep. 25873

Bellingham, S. A., Coleman, B. M., and Hill, A. F. (2012). Small RNA deep sequencing reveals a distinct miRNA signature released in exosomes from prion-infected neuronal cells. Nucleic Acids Res. 40, 10937-10949. doi: 10.1093/nar/gks832

Camussi, G., Deregibus, M. C., Bruno, S., Grange, C., Fonsato, V., and Tetta, C. (2011).Exosome/microvesiclemediated epigenetic reprogramming of cells. Am. J. Cancer Res. 1, 98-110. doi: 10.1093/hmg/dds317

Care, A., Catalucci, D., Felicetti, F., Bonci, D., Addario, A., Gallo, P.,

expression in the cells of an organism, many questions remain unanswered. How these RNAs pass through the body's epithelial lining barrier and enter the circulation, for example, is still completely unclear. Because of the relatively low levels of exogenous circulating RNA, it seems likely that if the packages containing exogenous RNAs exert a significant biological effect on the body's cells they must be effectively targeted in some way to specific cells or tissues.

Since some miRNAs are highly conserved in metazoans (Shi et al., 2012), the finding of diet derived exogenous RNA in circulation raises the interesting possibility that there are RNA-based processes that either induce or avert the development of diseases in humans arising from foreign RNA. For example, changing the levels of certain highly conserved miRNAs, such as miR-21, which has solid pro-proliferation activity (Sayed et al., 2008; Yao et al., 2009), and miR-150 and miR-146, which have strong association with inflammation activities (Sheedy and O'Neill, 2008; Sonkoly et al., 2008; Schmidt et al., 2009; Quinn and O'Neill, 2011; Zhong et al., 2012), by uptake of exogenous RNAs with similar activities may affect the initiation and progression of certain diseases.

Although promising both as biomarkers and potential functional impacts, such as for therapeutics, there is still a great deal to be learned about RNA in circulation. This newly recognized class of circulating molecules has the potential to be deeply involved in the symbiotic functioning of the human body and its microbiome. We currently know very little about the potential mechanisms of entry of RNAs into circulation, their mechanisms of action, their packaging and export process, and their targeting and uptake by cells. Technical improvements and standardization in measuring the levels of these RNAs as well as new model experimental systems are needed in order to explore the many facets of the transport, targeting, and function of these RNAs. In summary, the health impact of RNAs in circulation seems likely to be significant, but the field is just beginning to be explored and the investigation of the area of the quantitative characterization and specific biological functions of exogenous RNA is even earlier in its development.

et al. (2007). MicroRNA-133 controls cardiac hypertrophy. Nat. Med. 13, 613-618. doi: 10.1038/nm1582

Chen, X., Ba, Y., Ma, L., Cai, X., Yin, Y., Wang, K., et al. (2008). Characterization of microRNAs in serum: a novel class of biomarkers for diagnosis of cancer and other diseases. Cell Res. 18 , 997-1006. doi: 10.1038/cr.2008.282

Chendrimada, T. P., Finn, K. J., Ji, X., Baillat, D., Gregory, R. I., Liebhaber, S. A., et al. (2007). MicroRNA silencing through RISC recruitment of eIF6. Nature 447, 823-828. doi: 10.1038/nature05841

Cheng, Y., Tan, N., Yang, J., Liu, X., Cao, X., He, P., et al. (2010). A translational study of circulating cellfree microRNA-1 in acute myocardial infarction. Clin. Sci. (Lond.) 119, 87-95. doi: 10.1042/CS20090645

Chillakuri, C. R., Sheppard, D., Lea, S. M., and Handford, P. A.
(2012). Notch receptor-ligand binding and activation: insights from molecular studies. Semin. Cell Dev. Biol. 23, 421-428. doi: 10.1016/ j.semcdb.2012.01.009

Chim, S. S., Shing, T. K., Hung, E. C., Leung, T. Y., Lau, T. K., Chiu, R. W., etal. (2008). Detection and characterization of placental microRNAs in maternal plasma. Clin. Chem. 54, 482-90. doi: 10.1373/clinchem.2007.097972

Corsten, M. F., Dennert, R., Jochems, S., Kuznetsova, T., Devaux, Y., Hofstra, L., et al. (2010). Circulating microRNA-208b and microRNA499 reflect myocardial damage in cardiovascular disease. Circ. Cardiovasc. Genet. 3, 499-506. doi: 10.1161/CIRCGENETICS.110. 957415

Cortez, M. A., Bueso-ramos, C., Ferdin, J., Lopez-berestein, G., Sood, 
A. K., and Calin, G. A. (2011). MicroRNAs in body fluids - the mix of hormones and biomarkers. Nat. Rev. Clin. Oncol. 8, 467-477. doi: 10.1038/nrclinonc.2011.76

D’Alessandra, Y., Devanna, P., Limana, F., Straino, S., Di carlo, A., Brambilla, P. G., et al. (2010). Circulating microRNAs are new and sensitive biomarkers of myocardial infarction. Eur. Heart J. 31, 2765-2773. doi: 10.1093/eurheartj/ehq221

Devaux, Y., Vausort, M., Goretti, E., Nazarov, P. V., Azuaje, F., Gilson, G., etal. (2012). Use of circulating microRNAs to diagnose acute myocardial infarction. Clin. Chem. 58, 559-567. doi: 10.1373/ clinchem.2011.173823

Erener, S., Mojibian, M., Fox, J. K., Denroche, H. C., and Kieffer, T. J. (2013). Circulating miR-375 as a biomarker of beta-cell death and diabetes in mice. Endocrinology 154, 603-608 doi: 10.1210/en.2012-1744

Fabian, M. R., Sonenberg, N., and Filipowicz, W. (2010). Regulation of mRNA translation and stability by microRNAs. Annu. Rev. Biochem. 79, 351-379. doi: 10.1146/annurevbiochem-060308-103103

Filipowicz, W., Bhattacharyya, S. N., and Sonenberg, N. (2008). Mechanisms of post-transcriptional regulation by microRNAs: are the answers in sight? Nat. Rev. Genet. 9, 102-114. doi: 10.1038/nrg2290

Gerdes, H. H., and Carvalho, R. N. (2008). Intercellular transfer mediated by tunneling nanotubes. Curr. Opin. Cell Biol. 20, 470-475. doi: 10.1016/j.ceb.2008.03.005

Hanke, M., Hoefig, K., Merz, H., Feller, A. C., Kausch, I., Jocham, D., et al. (2010). A robust methodology to study urine microRNA as tumor marker: microRNA-126 and microRNA-182 are related to urinary bladder cancer. Urol. Oncol. 28, 655-661. doi: 10.1016/j.urolonc. 2009.01.027

Hergenreider, E., Heydt, S., Treguer, K. Boettger, T., Horrevoets, A. J., Zeiher, A. M., et al. (2012). Atheroprotective communication between endothelial cells and smooth muscle cells through miRNAs. Nat. Cell Biol. 14, 249-256. doi: $10.1038 /$ ncb2441

Higashijima, A., Miura, K., Mishima, H., Kinoshita, A., Jo, O., Abe, S., et al. (2013). Characterization of placentaspecific microRNAs in fetal growth restriction pregnancy. Prenat. Diagn. 33, 214-222. doi: 10.1002/pd.4045

Huang, X., Yuan, T., Tschannen, M. Sun, Z., Jacob, H., Du, M., et al. (2013). Characterization of human plasma-derived exosomal RNAs by deep sequencing. BMC Genomics 14:319. doi: 10.1186/1471-216414-319

Huang, Z., Huang, D., Ni, S., Peng, Z., Sheng, W., and Du, X. (2010). Plasma microRNAs are promising novel biomarkers for early detection of colorectal cancer. Int. J. Cancer 127, 118-126. doi: 10.1002/ijc. 25007

Hunter, M. P., Ismail, N., Zhang, X., Aguda, B. D., Lee, E. J. Yu, L., etal. (2008). Detection of microRNA expression in human peripheral blood microvesicles. PLoS ONE 3:e3694. doi: 10.1371/journal. pone.0003694

Ismail, N., Wang, Y., Dakhlallah, D., Moldovan, L., Agarwal, K., Batte, K. et al. (2013). Macrophage microvesicles induce macrophage differentiation and miR-223 transfer. Blood 121, 984-995. doi: 10.1182/blood-201108-374793

Janssen, H. L., Reesink, H. W., Lawitz, E. J., Zeuzem, S., Rodriguez-Torres M., Patel, K., et al. (2013). Treatment of HCV infection by targeting microRNA. N. Engl. J. Med. 368, 1685-1694. doi: 10.1056/NEJMoa1209026

Kogure, T., Lin, W. L., Yan, I. K., Braconi, C., and Patel, T. (2011). Intercellular nanovesicle-mediated microRNA transfer: a mechanism of environmental modulation of hepatocellular cancer cell growth. Hepatology 54, 1237-1248. doi: 10.1002/hep. 24504

Kohler, C., Barekati, Z., Radpour, R. and Zhong, X. Y. (2011). Cell-free DNA in the circulation as a potential cancer biomarker. Anticancer Res. 31, 2623-2628. doi: 10.1186/1476-45988-105

Kosaka, N., Iguchi, H., Yoshioka, Y., Takeshita, F., Matsuki, Y., and Ochiya, T. (2010). Secretory mechanisms and intercellular transfer of microRNAs in living cells. J. Biol. Chem. 285, 17442-17452. doi: 10.1074/jbc.M110.107821

Kuwabara, Y., Ono, K., Horie, T., Nishi, H., Nagao, K., Kinoshita, M., et al. (2011). Increased microRNA1 and microRNA-133a levels in serum of patients with cardiovascular disease indicate myocardial damage. Circ. Cardiovasc. Genet. 4, 446-454. doi: 10.1161/CIRCGENETICS.110.958975

Laterza, O. F., Lim, L., Garrett-Engele, P. W., Vlasakova, K., Muniappa, N., Tanaka, W. K., et al. (2009). Plasma microRNAs as sensitive and specific biomarkers of tissue injury. Clin. Chem. 55, 1977-1983. doi: 10.1373/clinchem.2009.131797
Lawrie, C. H., Gal, S., Dunlop, H. M., Pushkaran, B., Liggins, A. P., Pulford, K., et al. (2008). Detection of elevated levels of tumor-associated microRNAs in serum of patients with diffuse large B-cell lymphoma. $\mathrm{Br}$ J. Haematol. 141, 672-675. doi: 10.1111/j.1365-2141.2008.07077.x

Lee, L. W., Zhang, S., Etheridge, A., Ma, L., Martin, D., Galas, D., et al. (2010). Complexity of the microRNA repertoire revealed by next-generation sequencing. RNA 16, 2170-2180. doi: 10.1261/rna.2225110

Lee, S. T., Chu, K., Jung, K. H., Kim, J. H., Huh, J. Y., Yoon, H., et al. (2012). miR-206 regulates brain-derived neurotrophic factor in Alzheimer disease model. Ann. Neurol. 72, 269-277. doi: 10.1002/ ana. 23588

Lim, P. K., Bliss, S. A., Patel, S. A., Taborga, M., Dave, M. A., Gregory, L. A., et al. (2011). Gap junctionmediated import of microRNA from bone marrow stromal cells can elicit cell cycle quiescence in breast cancer cells. Cancer Res. 71, 1550-1560. doi 10.1158/0008-5472.CAN-10-2372

Liu, A. Y., Pascal, L. E., Vencio, R. Z. and Vencio, E. F. (2010). Stromalepithelial interactions in early neoplasia. Cancer Biomarker 9, 141-155. doi: 10.3233/CBM-2011-0174

Lo, Y. M., and Chiu, R. W. (2012). Genomic analysis of fetal nucleic acids in maternal blood. Annu. Rev. Genomics Hum. Genet. 13, 285306. doi: 10.1146/annurev-genom 090711-163806

Lotvall, J., and Valadi, H. (2007). Cell to cell signalling via exosomes through esRNA. Cell Adh. Migr. 1, 156-158. doi: 10.4161/cam.1.3.5114

Ma, Y., Zhang, P., Wang, F., Zhang, H., Yang, J., Peng, J., et al. (2012). miR150 as a potential biomarker associated with prognosis and therapeutic outcome in colorectal cancer. Gut 61, 1447-1453. doi: 10.1136/gutjnl2011-301122

Mandel, P., and Métais, P. (1948). Les acides nucléiques du plasma sanguin chez l'homme. C. R. Acad. Sci. Paris 142, 241-243. doi: 10.1373/ clinchem.2005.051003

Meckes, D. G. Jr., Shair, K. H. Y., Marquitz, A. R., Kung, C. P., Edwards, R. H., and RaabTraub, N. (2010). Human tumor virus utilizes exosomes for intercellular communication. Proc. Natl. Acad. Sci. U.S.A. 107, 20370-20375. doi: 10.1073/pnas.1014194107

Meder, B., Keller, A., Vogel, B., Haas, J., Sedaghat-Hamedani, F., Kayvanpour, E., et al. (2011). MicroRNA signatures in total peripheral blood as novel biomarkers for acute myocardial infarction. Basic Res. Cardiol. 106, 13-23. doi: 10.1007/s00395-0100123-2

Mitchell, P. S., Parkin, R. K., Kroh, E. M., Fritz, B. R., Wyman, S. K., Pogosova-Agadjanyan, E. L., et al. (2008). Circulating microRNAs as stable blood-based markers for cancer detection. Proc. Natl. Acad. Sci. U.S.A. 105, 10513-10518. doi: 10.1073/pnas.0804549105

Mittelbrunn, M., Gutierrez-Vazquez, C., Villarroya-Celtri, C., Gonzalez, S., Sanchez-Cabo, F., Gonzalez, M. A., et al. (2011). Unidirectional transfer of microRNA-loaded exosomes from $\mathrm{T}$ cells to antigen-presenting cells. Nat. Commun. 2, 282. doi: 10.1038/ncomms1285

Miyamoto, M., Yanai, M., Ookubo, S., Awasaki, N., Takami, K., and Imai, R. (2008). Detection of cell-free, liver-specific mRNAs in peripheral blood from rats with hepatotoxicity: a potential toxicological biomarker for safety evaluation. Toxicol. Sci. 106, 538-545. doi: 10.1093/toxsci/ kfn 188

Mizuno, H., Nakamura, A., Aoki, Y., Ito, N., Kishi, S., Yamamoto, K., et al. (2011). Identification of musclespecific microRNAs in serum of muscular dystrophy animal models: promising novel blood-based markers for muscular dystrophy. PLoS ONE 6:e18388. doi: 10.1371/journal.pone.0018388

Montecalvo, A., Larregina, A. T., Shufesky, W. J., Stolz, D. B., Sullivan, M. L., Karlsson, J. M., et al. (2012). Mechanism of transfer of functional microRNAs between mouse dendritic cells via exosomes. Blood 119, 756766. doi: 10.1182/blood-2011-02338004

Moussay, E., Wang, K., Cho, J. H., van Moer, K., Pierson, S., Paggetti, J., et al. (2011). MicroRNA as biomarkers and regulators in B-cell chronic lymphocytic leukemia. Proc. Natl. Acad. Sci. U.S.A. 108, 6573-6578. doi: 10.1073/pnas.1019557108

Muller, G. (2012). Microvesicles/ exosomes as potential novel biomarkers of metabolic diseases. Diabetes Metab. Syndr. Obes. 5, 247-282. doi: 10.2147/DMSO.S32923

Ohshima, K., Inoue, K., Fujiwara, A., Hatakeyama, K., Kanto, K., Watanabe, Y., et al. (2010). Let-7 microRNA family is selectively secreted into the extracellular environment via exosomes in a metastatic gastric cancer cell line. PLoS ONE 5:e13247. doi: 10.1371/journal.pone.0013247

Okubo, S., Miyamoto, M., Takami, K., Kanki, M., Ono, A., Nakatsu, 
N., et al. (2013). Identification of novel liver-specific mRNAs in plasma for biomarkers of drug-induced liver injury and quantitative evaluation in rats treated with various hepatotoxic compounds. Toxicol. Sci. 132, 21-31. doi: $10.1093 /$ toxsci/kfs340

Park, N. J., Zhou, H., Elashoff, D., Henson, B. S., Kastratovic, D. A., Abemayor, E., et al. (2009). Salivary microRNA: discovery, characterization, and clinical utility for oral cancer detection. Clin. Cancer Res. 15, 5473-5477. doi: 10.1158/10780432.CCR-09-0736

Pegtel, D. M., Cosmopoulos, K., Thorley-Lawson, D. A., van Eijndhoven, M. A., Hopmans, E. S., Lindenberg, J. L., et al. (2010). Functional delivery of viral miRNAs via exosomes. Proc. Natl. Acad. Sci. U.S.A. 107, 6328-6333. doi: 10.1073/ pnas.0914843107

Quinn, S. R., and O'Neill, L. A. (2011). A trio of microRNAs that control toll-like receptor signaling. Int. Immunol. 23, 421-425. doi: 10.1093/intimm/dxr034

Rajakumar, A., Cerdeira, A. S., Rana, S., Zsengeller, Z., Edmunds, L. Jeyabalan, A., etal. (2012). Transcriptionally active syncytial aggregates in the maternal circulation may contribute to circulating soluble fms-like tyrosine kinase 1 in preeclampsia. Hypertension 59, 256264. doi: 10.1161/HYPERTENSIONAHA.111.182170

Ratajczak, J., Miekus, K., Kucia, M., Zhang, J., Reca, R., Dvorak, P., et al. (2006). Embryonic stem cell-derived microvesicles reprogram hematopoietic progenitors: evidence for horizontal transfer of mRNA and protein delivery. Leukemia 20, 847-856. doi: 10.1038/sj.leu.2404132

Roth, P., Wischhusen, J., Happold, C., Chandran, P. A., Hofer, S., Eisele, G., et al. (2011). A specific miRNA signature in the peripheral blood of glioblastoma patients. J. Neurochem. 118, 449-457. doi: 10.1111/j.14714159.2011.07307.x

Sayed, D., Rane, S., Lypowy, J., He, M., Chen, I. Y., Vashistha, H., et al. (2008). MicroRNA-21 targets Sprouty 2 and promotes cellular outgrowths. Mol. Biol. Cell 19, 32723282. doi: 10.1091/mbc.E08-02-0159

Schmidt, W. M., Spiel, A. O., Jilma, B., Wolzt, M., and Muller, M. (2009). In vivo profile of the human leukocyte microRNA response to endotoxemia. Biochem. Biophys. Res. Commun. 380, 437-441. doi: 10.1016/ j.bbrc.2008.12.190

Schonbeck, U., and Libby, P. (2001). The CD40/CD154 receptor/ligand dyad.
Cell. Mol. Life Sci. 58, 4-43. doi: 10.1007/PL00000776

Selvamani, A., Sathyan, P., Miranda R. C., and Sohrabji, F. (2012). An antagomir to microRNA Let7f promotes neuroprotection in an ischemic stroke model. PLoS ONE 7:e32662. doi: 10.1371/journal.pone. 0032662

Semenov, D. V., Baryakin, D. N., Brenner, E. V., Kurilshikov, A. M., Vasiliev, G. V., Bryzgalov, L. A., et al. (2012). Unbiased approach to profile the variety of small non-coding RNA of human blood plasma with massively parallel sequencing technology. Expert Opin. Biol. Ther. 12(Suppl. 1), S43-S51. doi: 10.1517/ 14712598.2012.679653

Sheedy, F. J., and O'Neill, L. A. (2008). Adding fuel to fire: microRNAs as a new class of mediators of inflammation. Ann. Rheum. Dis. 67(Suppl. 3), iii50-iii55. doi: 10.1136/ard.2008.100289

Shi, B., Gao, W., and Wang, J. (2012). Sequence fingerprints of microRNA conservation. PLoS ONE 7:e48256. doi: 10.1371/journal.pone. 0048256

Skog, J., Wurdinger, T., van Rijn, S., Meijer, D. H., Gainche, L. Sena-Esteves, M., et al. (2008). Glioblastoma microvesicles transport RNA and proteins that promote tumour growth and provide diagnostic biomarkers. Nat. Cell Biol. 10, 1470-1476. doi: 10.1038/ncb1800

Sonkoly, E., Stahle, M., and Pivarcsi, A. (2008). MicroRNAs and immunity: novel players in the regulation of normal immune function and inflammation. Semin. Cancer Biol. 18, 131-140. doi: 10.1016/j.semcancer. 2008.01 .005

Starkey Lewis, P. J., Dear, J., Platt, V., Simpson, K. J., Craig, D. G. Antoine, D. J., et al. (2011). Circulating microRNAs as potential markers of human drug-induced liver injury. Hepatology 54, 1767-1776. doi: 10.1002/hep. 24538

Su, Y. W., Chen, X., Jiang, Z. Z., Wang, T., Wang, C., Zhang, Y., et al. (2012). A panel of serum microRNAs as specific biomarkers for diagnosis of compound- and herb-induced liver injury in rats. PLoS ONE 7:e37395. doi: 10.1371/journal.pone.0037395

Suckau, L., Fechner, H., Chemaly, E. Krohn, S., Hadri, L., Kockskamper J., et al. (2009). Long-term cardiactargeted RNA interference for the treatment of heart failure restores cardiac function and reduces pathological hypertrophy. Circulation 119, 1241-1252. doi: 10.1161/CIRCULATIONAHA.108.783852
Sueoka, E., Sueoka, N., Iwanaga, K., Sato, A., Suga, K., Hayashi, S., et al. (2005). Detection of plasma hnRNP B1 mRNA, a new cancer biomarker, in lung cancer patients by quantitative real-time polymerase chain reaction. Lung Cancer 48, 77-83. doi: 10.1016/j.lungcan.2004.10.007

Taylor, D. D., and Gercel-Taylor, C. (2008). MicroRNA signatures of tumor-derived exosomes as diagnostic biomarkers of ovarian cancer. Gynecol. Oncol. 110, 13-21. doi: 10.1016/j.ygyno.2008.04.033

Tijsen, A. J., Creemers, E. E., Moerland, P. D., de Windt, L. J., van der Wal, A. C., Kok, W. E., et al (2010). MiR423-5p as a circulating biomarker for heart failure. Circ. Res. 106, 1035-1039. doi: 10.1161/CIRCRESAHA.110.218297

Turchinovich, A., and Burwinkel, B. (2012). Distinct AGO1 and AGO2 associated miRNA profiles in human cells and blood plasma. RNA Biol. 9, 1066-1075. doi: 10.4161/rna.21083

Turchinovich, A., Weiz, L., Langheinz, A., and Burwinkel, B. (2011). Characterization of extracellular circulating microRNA. Nucleic Acids Res. 39 , 7223-7233. doi: 10.1093/nar/gkr254

Valadi, H., Ekstrom, K., Bossios, A., Sjostrand, M., Lee, J. J., and Lotvall, J. O. (2007). Exosome-mediated transfer of mRNAs and microRNAs is a novel mechanism of genetic exchange between cells. Nat. Cell Biol. 9, 654-659. doi: 10.1038/ ncb 1596

Valiunas, V., Polosina, Y. Y., Miller, H., Potapova, I. A., Valiuniene, L., Doronin, S., et al. (2005). Connexin-specific cell-to-cell transfer of short interfering RNA by gap junctions. J. Physiol. 568, 459-468. doi: 10.1113/jphysiol.2005.090985

van Solingen, C., Seghers, L., Bijkerk, R., Duijs, J. M., Roeten, M. K., van Oeveren-Rietdijk, A. M., et al. (2009). Antagomir-mediated silencing of endothelial cell specific microRNA-126 impairs ischemiainduced angiogenesis. J. Cell. Mol. Med. 13, 1577-1585. doi: 10.1111/ j.1582-4934.2008.00613.x

Vencio, E. F., Pascal, L. E., Page, L. S., Denyer, G., Wang, A. J., RuoholaBaker, H., et al. (2011). Embryonal carcinoma cell induction of miRNA and mRNA changes in co-cultured prostate stromal fibromuscular cells. J. Cell. Physiol. 226, 1479-1488. doi: 10.1002/jcp.22464

Vickers, K. C., Palmisano, B. T., Shoucri, B. M., Shamburek, R. D., and Remaley, A. T. (2011). MicroRNAs are transported in plasma and delivered to recipient cells by high-density lipoproteins. Nat. Cell Biol. 13, 423433. doi: $10.1038 /$ ncb2210

Vignier, N., Amor, F., Fogel, P., Duvallet, A., Poupiot, J., Charrier, S., et al. (2013). Distinctive serum miRNA profile in mouse models of striated muscular pathologies. PLoS ONE 8:e55281. doi: 10.1371/journal.pone.0055281

Wagner, J., Riwanto, M., Besler, C., Knau, A., Fichtlscherer, S., Roxe, T., et al. (2013). Characterization of levels and cellular transfer of circulating lipoprotein-bound microRNAs. Arterioscler. Thromb. Vasc. Biol. 33, 1392-1400. doi: 10.1161/ ATVBAHA.112.300741

Wang, G. K., Zhu, J. Q., Zhang, J. T., Li, Q., Li, Y., He, J., et al. (2010a). Circulating microRNA: a novel potential biomarker for early diagnosis of acute myocardial infarction in humans. Eur. Heart J. 31, 659-666. doi: 10.1093/eurheartj/ ehq013

Wang, K., Zhang, S., Weber, J., Baxter, D., and Galas, D. J. (2010b). Export of microRNAs and microRNAprotective protein by mammalian cells. Nucleic Acids Res. 38, 72487259. doi: 10.1093/nar/gkq601

Wang, K., Li, H., Yuan, Y., Etheridge, A., Zhou, Y., Huang, D., et al. (2012). The complex exogenous RNA spectra in human plasma: an interface with human gut biota? PLoS ONE 7:e51009. doi: 10.1371/journal. pone.0051009

Wang, K., Yuan, Y., Li, H., Cho, J. H., Huang, D., Gray, L., et al. (2013). The spectrum of circulating RNA, a window into systems toxicology. Toxicol. Sci. 132, 478-492. doi: 10.1093/toxsci/kft014

Wang, K., Zhang, S., Marzolf, B., Troisch, P., Brightman, A., Hu, Z., etal. (2009). Circulating microRNAs, potential biomarkers for druginduced liver injury. Proc. Natl. Acad. Sci. U.S.A. 106, 4402-4407. doi: 10.1073/pnas.0813371106

Wang, R., Li, N., Zhang, Y., Ran, Y., and $\mathrm{Pu}, \quad$ J. (2011). Circulating microRNAs are promising novel biomarkers of acute myocardial infarction. Intern. Med. 50, 17891795. doi: 10.2169/internalmedicine. 50.5129

Weber, J. A., Baxter, D. H., Zhang, S., Huang, D. Y., Huang, K. H., Lee, M. J., et al. (2010). The microRNA spectrum in 12 body fluids. Clin. Chem. 56, 1733-1741. doi: 10.1373/clinchem.2010.147405

Wolvetang, E. J., Pera, M. F., and Zuckerman, K. S. (2007). Gap junction mediated transport of shRNA between human embryonic 
stem cells. Biochem. Biophys. Res. Commun. 363, 610-615. doi: 10.1016/j.bbrc.2007.09.035

Wu, L., Zhou, H., Lin, H., Qi, J., Zhu, C., Gao, Z., et al. (2012). Circulating microRNAs are elevated in plasma from severe preeclamptic pregnancies. Reproduction 143, 389-397. doi: 10.1530/REP-11-0304

Yang, M., Chen, J., Su, F., Yu, B., Lin, L., Liu, Y., et al. (2011). Microvesicles secreted by macrophages shuttle invasion-potentiating microRNAs into breast cancer cells. Mol. Cancer 10, 117. doi: 10.1186/1476-4598-10117

Yao, Q., Xu, H., Zhang, Q. Q., Zhou, H., and Qu, L. H. (2009). MicroRNA21 promotes cell proliferation and down-regulates the expression of programmed cell death 4 (PDCD4) in HeLa cervical carcinoma cells. Biochem. Biophys. Res. Commun. 388, 539-542. doi: 10.1016/j.bbrc.2009. 08.044
Zhang, L., Hou, D., Chen, X., Li, D. Zhu, L., Zhang, Y., et al. (2012a). Exogenous plant MIR168a specifically targets mammalian LDLRAP1: evidence of cross-kingdom regulation by microRNA. Cell Res. 22, 107-126. doi: 10.1038/cr.2011.158

Zhang, X., Wang, C., Wang, L., Du, L., Wang, S., Zheng, G., et al. (2012b). Detection of circulating Bmi-1 mRNA in plasma and its potential diagnostic and prognostic value for uterine cervical cancer. Int. J. Cancer 131, 165-172. doi: 10.1002/ijc. 26360

Zhang, Y., Liu, D., Chen, X. Li, J., Li, L., Bian, Z., et al. (2010). Secreted monocytic miR150 enhances targeted endothelial cell migration. Mol. Cell 39, 133-144. doi: 10.1016/j.molcel.2010.06.010

Zhao, H., Shen, J., Medico, L., Wang, D., Ambrosone, C. B., and Liu, S. (2010). A pilot study of circulating miRNAs as potential biomarkers of early stage breast cancer. PLoS ONE 5:e13735. doi: 10.1371/journal.pone. 0013735

Zhao, Z., Zhao, Q., Warrick, J., Lockwood, C. M., Woodworth, A., Moley, K. H., etal. (2012). Circulating microRNA miR-323-3p as a biomarker of ectopic pregnancy. Clin. Chem. 58, 896-905. doi: 10.1373/clinchem.2011.179283

Zhong, S., Zhang, S., Bair, E., Nares, S., and Khan, A. A. (2012). Differential expression of microRNAs in normal and inflamed human pulps. J. Endod. 38, 746-752. doi: 10.1016/j.joen.2012.02.020

Zhong, X. Y., Holzgreve, W., and Huang, D. J. (2008). Isolation of cell-free RNA from maternal plasma. Methods Mol. Biol. 444, 269-273. doi: 10.1007/978-1-59745-066-9_21

Conflict of Interest Statement: The authors declare that the research was conducted in the absence of any commercial or financial relationships that could be construed as a potential conflict of interest.

Received: 18 April 2013; accepted: 31 May 2013; published online: 18 June 2013.

Citation: Etheridge A, Gomes CPC, Pereira RW, Galas D and Wang K (2013) The complexity, function, and applications of RNA in circulation. Front. Genet. 4:115. doi: 10.3389/fgene.2013.00115

This article was submitted to Frontiers in Non-Coding RNA, a specialty of Frontiers in Genetics.

Copyright (c) 2013 Etheridge, Gomes, Pereira, Galas and Wang. This is an openaccess article distributed under the terms of the Creative Commons Attribution License, which permits use, distribution and reproduction in other forums, provided the original authors and source are credited and subject to any copyright notices concerning any third-party graphics etc. 